\title{
Kepatuhan Bank Syariah Terhadap Pembiayaan Murabahah (Studi Kasus Pada BPRS Mitra Mentari Sejahtera Ponorogo)
}

\author{
Anton Sudrajat \\ IAIN Syekh Nurjati Cirebon \\ antonsudrajat@syekhnurjati.ac.id
}

\begin{abstract}
Many harsh criticisms have been addressed at Islamic banks, especially on the practice of murabahah financing, suggesting that Islamic banks are considered not to have complied with sharia provisions regarding 'aqad murabahah. However, so far there has been no uniform standard or parameter to judge that Islamic banks are compliant or non-compliant, each party has its own standards or parameters resulting in a different assessment. This study aims to apply the maqāșid syarī'ah approach to the conception of At-Tähir bin 'Asyūr to assess how BPR Syariah Mitra Mentari Sejahtera Ponorogo complies with murabahah financing. The research method used is descriptive qualitative research method using Miles and Huberman analysis techniques. The results of this study indicate that BPR Syariah Mitra Mentari Sejahtera Ponorogo has fulfilled the maqāșid of circulation, maqāșid of transparency, maqāșid of legal force, and maqāșid of justice very well, except maqāșid of preservation, so that murabahah financing transactions run by BPR Syariah Mitra Mentari Sejahtera Ponorogo are considered valid according to the concept maqāșid syarī'ah At t-Tăhir bin 'Asyür. The implication of this research is that Islamic banking practitioners should use maqūșid syarīah conception syarī'ah At-Tăhir bin 'Asyür as an assessment of Islamic bank compliance with murabahah financing provisions.
\end{abstract}

Keywords: Murabahah, Maqāṣid Syarī’ah, Aṭ-Ṭāhir bin ‘Āsyūr.

\begin{abstract}
Abstrak
Banyak kritik tajam yang dilayangkan kepada bank syariah terutama pada praktek pembiayaan murabahah mengisyaratkan bahwa bank syariah dianggap belum mematuhi ketentuan syariah tentang 'aqad murabahah. Namun, selama ini belum ada standar atau parameter yang seragam untuk menilai bahwa bank syariah patuh atau tidak patuh, masing-masing pihak memiliki standar atau parameter masing-masing sehingga menghasilkan penilaian yang berbeda. Penelitian ini bertujuan mengaplikasikan pendekatan maqāṣid syarī'ah konsepsi Aț-Ṭăhir bin 'Assyūr untuk menilai bagaimana
\end{abstract}


kepatuhan BPR Syariah Mitra Mentari Sejahtera Ponorogo terhadap pembiayaan murabahah. Metode penelitian yang digunakan adalah metode penelitian kualitatif deskriptif dengan menggunakan teknik analisis Miles dan Huberman. Hasil penelitian ini menunjukkan bahwa BPR Syariah Mitra Mentari Sejahtera Ponorogo telah memenuhi maqāṣid sirkulasi, maqāṣid transparansi, maqāṣid kekuatan hukum, dan maqāṣid keadilan dengan sangat baik, kecuali maqāṣid preservasi sehingga transaksi pembiayaan murabahah yang dijalankan oleh BPR Syariah Mitra Mentari Sejahtera Ponorogo dianggap sah sesuai dengan konsep maqāssid syarī'ah At-Tāhir bin 'Assyür. Implikasi dari penelitian ini adalah hendaknya praktisi perbankan syariah menggunakan maqāsid syari 'ah konsepsi at-Tāhir bin 'Asyür sebagai assesment kepatuhan bank syariah terhadap ketentuan pembiayaan murabahah.

Kata Kunci: Murabahah, Maqāṣid Syarī'ah, At-Tāhhir bin 'Āsyūr.

\section{PENDAHULUAN}

Kehadiran bank syariah di Indonesia semenjak tahun 1991 memberikan alternatif pilihan bagi masyarakat yang menginginkan bebas dari bunga ketika bertransaksi dengan perbankan. Namun, semenjak awal kehadiran bank syariah di Indonesia belum menunjukkan perkembangan yang cukup menggembirakan dari sisi pertumbuhan bisnisnya, karena rendahnya kesadaran masyarakat Indonesia untuk bertransaksi dengan bank syariah yang bukan disebabkan persoalan teknis seperti layanan, jaringan kantor, produk, dan lain-lain, tapi lebih kepada persoalan non teknis yaitu kurangnya pemahaman yang benar dan utuh dari masyarakat tentang praktik sistem keuangan syariah yang dijalankan oleh bank syariah (Aditiasari, 2017). Hal ini berdampak pada munculnya keraguan dan keengganan bahkan tudingan miring yang dilontarkan dari sebagian orang bahwa bank syariah sama saja dengan bank konvensional bedanya hanya pada istilah, bank syariah masih mengandung riba, dan bank syariah dianggap menyimpang dari ketentuan syariah dalam operasionalisasi produk-produk penghimpunan dan penyaluran dana (Ibrahim, 2015).

Menurut Abozaid \& Dusuki terdapat kesan secara umum dari masyarakat bahwa secara operasional bank syariah dianggap "old skeleton in modern dress", yaitu menjalankan praktik seperti bank konvensional tapi dengan kemasan produk yang baru. Hal ini nampak pada pembiayaan berbasis hutang (debt-based instrument) yang disinyalir mirip dengan praktek bunga di bank konvensional karena bank syariah hanya memberikan hutang kepada nasabah melalui 'aqad jual 
beli dengan tingkat keuntungan yang bersifat pasti, tidak seperti pembiayaan berbasis profit and loss sharing (equity-based instrument) dimana bank syariah memiliki potensi untuk mendapatkan keuntungan atau menderita kerugian tergantung pada usaha nasabah (Dusuki \& Abozaid, 2007).

Salah satu pembiayaan berbasis hutang (debt-based instrument) adalah pembiayaan murabahah yang jamak dijalankan oleh bank-bank syariah di Indonesia. Namun, banyak kalangan awan dan ulama yang mengkritik praktik pembiayaan murabahah yang dijalankan oleh bank syariah karena dianggap menyimpang, tidak sesuai dengan syariah, cenderung menjadi batil bahkan berpotensi menjadi zalim. Penyimpangan-penyimpangan tersebut diantaranya adalah: pelanggaran syarat milkiyyah, pelanggaran syarat ra's al-māl al-ma'lum, penempatan 'aqad yang tidak tepat, dan melibatkan maysir dalam perhitungan margin keuntungan (Sulaiman, 2016).

Banyaknya kritik terhadap pembiayaan murabahah tentunya menjadi kontra produktif pada perkembangan bank syariah di Indonesia yang sampai hari ini masih sangat memprihatinkan. Meskipun sudah 27 tahun berdiri (dihitung dari awal berdiri bank Muamalat tahun 1991) market sharenya baru mencapai 5,44\%(Otoritas Jasa Keuangan, 2018). Capaian ini masih berada jauh di bawah negara-negara lain. Misalnya negara tetangga seperti Malaysia telah mencapai 23,8\%, Arab Saudi sudah mencapai 51,1\%, dan Uni Emirat Arab sudah mencapai 19,6\% (Afrianto, 2018). Selain itu, kritik-kritik tersebut mengarah pada tudingan miring dari berbagai pihak bahwa bank syariah dianggap tidak patuh pada ketentuan syariah tentang pembiayaan murabahah. Namun, standar atau parameter apa yang dipakai untuk menilai bahwa bank syariah patuh atau tidak patuh? Padahal untuk menilai kepatuhan bank syariah membutuhka adanya standar atau parameter, karena selama ini belum ada standar atau parameter yang seragam, masing-masing pihak memiliki standar atau parameter masing-masing sehingga menghasilkan penilaian yang berbeda.

Beberapa peneliti telah melakukan kajian terhadap standar atau parameter untuk menilai kepatuhan bank syariah, diantaranya adalah Rosly yang menawarkan 4 (empat) pendekatan yang dapat dilakukan untuk menilai kepatuhan bank syariah terhadap prinsip-prinsip syariah, yaitu: 'aqad, maqāșid syarīah, laporan keuangan, dan dokumen legalitas (Rosly, 2010). Kemudian Mohammed \& Razak mengembangkan maqāșid syarīah indeks untuk mengukur kepatuhan bank Islam berdasarkan maqāșid syarīah yang bersumber dari pemikiran Abu Zahrah dengan mengklasifikasikan maqāṣid syarī‘ah, terdiri dari: 1) 
mendidik individu, 2) menegakkan keadilan, dan 3) memelihara kemasalahatan (Mohammed et al., 2008). Namun penelitian-penelitian ini hanya menghasilkan penilaian pada aspek kinerja bank syariah secara umum, sehingga masih membutuhkan standar atau parameter yang lebih sepisifik yang dapat menilai kepatuhan bank syariah terhadap pembiayaan murabahah dengan menggunakan pendekatan maqāșid syarī‘ah.

Untuk menilai bagaimana kepatuhan suatu bank syariah terhadap pembiayaan murabahah, penelitian ini menawarkan konsepsi maqāṣid syarīah yang digagas oleh seorang ulama kontemporer, At-Ṭāhir bin 'Āsyūr (w 1393 H) yang menguasai usul fikih melalui karyanya berjudul Maqāṣid asy-Syarīah alIslāmiyah, memiliki gagasan maqāṣid syarī‘ah khusus dalam bidang hukum niaga atau transaksi pertukaran harta, yaitu: sirkulasi (ar-rawāj), transparansi, kekuatan hukum, perlindungan (preservasi), dan keadilan ('Āsyūr, 2001). Kelima maqāṣid syarīah khusus dalam transaksi pertukaran harta ini menurut Ibn 'Āsyūr merupakan rujukan sah-tidak sahnya suatu 'aqad muamalah dan ketentuanketentuan teknis yang menjadi bagian 'aqad tersebut. Suatu 'aqad dipandang sah bilamana kelima maqāșid syarī'ah dimaksud terpenuhi, jika salah satu maqāșid tidak terpenuhi maka 'aqad tersebut pada dasarnya tidak sah.

Berdasarkan latar belakang di atas, penelitian ini bertujuan mengaplikasikan pendekatan maqāșid syarī'ah konsepsi Aț-Ṭāhir bin 'Āsyūr untuk menilai bagaimana kepatuhan BPR Syariah Mitra Mentari Sejahtera Ponorogo terhadap pembiayaan murabahah. Dimana BPR Syariah Mitra Mentari Sejahtera merupakan pemain baru dalam industri bank syariah di Kabupaten Ponorogo yang baru mendapatkan izin operasional tahun 2016, namun mampu menyalurkan pembiayaan sebanyak Rp 6,5 Milyar dan berhasil menghimpun dana masyarakat melalui tabungan sebesar Rp 3,5 Milyar dan Deposito sebesar Rp 1,8 Milyar pada akhir tahun 2017.

\section{KAJIAN LITERATUR}

Nama lengkap Aṭ-Tāhir bin 'Āsyūr (w 1393 H) adalah Muhammad aț-Ṭāhir bin Muhammad bin Muhammad aț-Ṭāhir bin 'Āsyūr. Beliau dilahirkan tahun 1296H/1879M dan meninggal pada tahun 1393H/1973M. Pada masa hidupnya beliau adalah seorang ketua Mufti untuk mazhab Maliki di Tunisia dan seorang Syaikh (Guru Besar) pada Universitas Zaitunah dan seluruh cabangnya di Tunisia, dan menjadi anggota Majelis Arab di Damaskus dan di Kairo. Beliau banyak 
memiliki karya-karya yang masyhur diantaranya adalah: Maqāsid asy-Syari 'ah alIslamiyah, Ușul An-Nizam al-Ijtima'iy fí al-Islām, At-Tahrïr wa At-Tanwïr (kitab tafsir yang terdiri dari 10 Jilid), al-Waqfu wa Aśäruhu fí al-Islām, Ușul al-Insya' wa al-Khitabah, Mujizul al-Balagah, dan banyak tulisan yang diterbitkan di berbagai majalah (Al-Galy, 1996).

Aṭ-Ṭāhir bin 'Āsyūr dalam karyanya Maqāṣid asy-Syarī'ah al-Islāmiyah mengklasifikasikan maqāșid asy-syarīah menjadi 2 (dua) bagian pembahasan, yaitu: 1) maqāșid umum dari pengaturan hukum (tasyri'), yaitu: memelihara fitrah, toleransi, menghadirkan maslạ̣at dan menghilangkan muḍarat, merubah keburukan dan menetapkan kebaikan, kesetaraan, dan kebebasan, dan 2) maqāșid khusus dalam bidang muamalah, seperti: hukum keluarga, hukum tata niaga, muamalat ketenagakerjaan, hukum tabarru'a $\bar{t}$, hukum peradilan dan persaksian, dan sanksi pidana ('Āsyūr, 2001). Sedangkan maqāṣid asy-syarī'ah khusus dalam bidang hukum niaga atau transaksi pertukaran harta adalah:

\section{Sirkulasi (ar-Rawāj]}

Menurut Aț-Ṭāhir bin 'Āsyūr, sirkulasi (ar-rawāj) merupakan bagian dari tujuan syariah (maqāșid syañ̄ah) agar 'aqad transaksi pertukaran harta dapat menciptakan distribusi atau perpindahan harta diantara manusia dengan caracara yang hak ('Āsyūr, 2001). Konstruk ini jika diterapkan pada 'aqad transaksi pertukaran harta merupakan tujuan 'aqad (maudu' al- 'aqd) yaitu maksud pokok yang hendak diwujudkan oleh para pihak. Tujuan 'aqad dalam jual beli adalah memindahkan kepemilikan atas suatu benda dengan imbalan sebagai manifestasi riil, yaitu pertukaran yang timbal balik dan merupakan sumber kekuatan mengikat bagi penjual untuk memindahkan kepemilikan atas barang kepada pembeli dan bagi pembeli untuk melakukan pembayaran harga kepada penjual (Anwar, 2007). Maka dimensi dari konstruk sirkulasi (ar-rawāj) adalah: 1) pemindahan hak milik atas barang kepada pembeli, dan 2) pembayaran harga oleh pembeli kepada penjual (Otoritas Jasa Keuangan, 2016).

\section{Transparansi}

Menurut Aț-Ṭāhir bin 'Āsyūr, transparansi merupakan bagian dari tujuan syariah (maqāșid syañ'ah) agar 'aqad transaksi pertukaran harta terhindar dari bahaya perselisihan dan pertengkaran, maka harus ada kejelasan bentuk atau wujud dan batasan harta yang ditransaksikan ('Āsyūr, 2001). Konstruk ini jika diterapkan pada 'aqad transaksi pertukaran harta merupakan objek 'aqad 
(mahal al- 'aqd) yaitu obyek yang menjadi sasaran yang hendak dicapai oleh para pihak melalui penutupan 'aqad. Objek 'aqad dapat berupa benda, manfaat benda, jasa atau pekerjaan, atau suatu yang lain yang tidak bertentangan dengan syariah. Objek 'aqad memiliki syarat yang harus dipenuhi oleh pelaku 'aqad, yaitu: dapat diserahkan atau dapat dilaksanakan, harus tertentu atau dapat ditentukan, dan dapat ditransaksikan menurut syarak (Anwar, 2007). Maka dimensi dari konstruk transparansi adalah: 1) objek 'aqad dapat diserahkan atau dapat dilaksanakan, 2) objek 'aqad harus tertentu atau dapat ditentukan, dan 3) objek 'aqad dapat ditransaksikan menurut syarak (Otoritas Jasa Keuangan, 2016).

\section{Kekuatan Hukum}

Menurut Aț-Tāahir bin 'Āsyūr, kekuatan hukum merupakan bagian dari tujuan syariah (maqāṣid syan̄'ah) agar 'aqad transaksi pertukaran harta memberikan kekuatan hukum terhadap pemindahan kepemilikan harta diantara pihak yang bertransaksi ('Āsyūr, 2001). Transaksi pertukaran harta agar memiliki legalitas yang kuat membutuhkan 'aqad. 'Aqad sendiri adalah pertemuan kehendak para pihak dan kehendak itu diungkapkan melalui pernyataan kehendak yang berupa ucapan atau bentuk ungkapan lain dari masing-masing pihak. Artinya, dalam 'aqad membutuhkan yang namanya para pihak yang membuat 'aqad (al-'aqidain) yang memenuhi syarat dan pernyataan kehendak (sigah 'aqad) yang memenuhi syarat (Anwar, 2007). Maka dimensi dari konstruk kekuatan hukum adalah: 1) para pihak yang memenuhi syarat, dan 2) pernyataan kehendak yang memenuhi syarat (Otoritas Jasa Keuangan, 2016).

\section{Preservasi}

Menurut Aț-Tāhir bin 'Āsyūr, preservasi merupakan bagian dari tujuan syariah (maqāșid syan̄'ah) agar 'aqad transaksi pertukaran harta dapat menciptakan perlindungan terhadap harta dari pemindahan kepemilikan secara batil ('Āsyūr, 2001). Harta agar terlindungi dari transfer kepemilikan secara batil tergantung pada kekuatan perjanjian yang mengikat para pihak untuk memenuhi dan tanggungjawab terhadap 'aqad (Anwar, 2007). Maka dimensi dari konstruk preservasi adalah: 1) Kewajiban memenuhi 'aqad, dan 2) Tanggungjawab terhadap 'aqad (Otoritas Jasa Keuangan, 2016). 


\section{Keadilan}

Menurut Aț-Tāahir bin 'Āsyūr, keadilan merupakan bagian dari tujuan syariah (maqāșid syan̄‘ah) agar 'aqad transaksi pertukaran harta tidak merugikan pihak lain dalam hal pemerolehan harta ('Āsyūr, 2001). Agar tidak merugikan pihak lain dalam transaksi pertukaran harta harus dilandasi dengan asas keseimbangan dan asas keadilan. Asas keseimbangan tercermin dari keseimbangan para pihak dalam bertransaksi dan keseimbangan dalam memikul risiko. Sedangkan asas keadilan bertumpu pada kesempatan bagi para pihak untuk melakukan negoisasi mengenai klausul 'aqad (Anwar, 2007). Maka dimensi dari konstruk keadilan adalah: 1) Keseimbangan dalam transaksi, 2) Keseimbangan memikul risiko, dan 3) Kesempatan melakukan negoisasi klausul 'aqad (Otoritas Jasa Keuangan, 2016).

\section{METODE PENELITIAN}

Metode penelitian yang digunakan adalah metode penelitian kualitatif deskriptif (Moleong, 2005). Tipe dan strategi dalam penelitian ini adalah studi kasus untuk mengungkap gambaran yang mendalam dan mendetail bagaimana BPRS Mitra Mentari Sejahtera Ponorogo beroperasi dalam menjalankan fungsi kepatuhan syariah sesuai dengan konteksnya (Yusuf, 2014). Penentuan sumber informasi (informan) dilakukan secara purposive sampling dengan tujuan atau pertimbangan bahwa informan adalah karyawan BPR Syariah yang memahami bagaimana mekanisme pembiayaan murabahah dari proses pengajuan, pencairan, perikatan kontrak, pembayaran, dan pelunasan. Pengumpulan data dalam penelitian ini melalui penelitian lapangan (field research) dengan teknik dokumentasi dan wawancara. Analisis data dalam penelitian ini menggunakan analisis Miles dan Huberman dimana analisis data kualitatif dilakukan secara interaktif dan berlangsung secara terus menerus sampai tuntas dengan kegiatan reduksi data (data reducation), penyajian data (data display), dan pengambilan kesimpulan (conclusion) untuk menggambarkan dan menyimpulkan bagaimana kepatuhan BPRS Mitra Mentari Sejahtera Ponorogo terhadap pembiayaan murabahah berdasarkan maqāṣid syarīah (Sugiyono, 2008). Sedangkan untuk mengukur kepatuhan dengan cara membandingkan bagaimana BPRS Mitra Mentari Sejahtera Ponorogo menjalankan pembiayaan murabahah pada setiap dimensi dari konsepsi maqāsid syarī'ah aṭ-Tāhir bin 'Āsyūr dengan standar produk murabahah yang dikeluarkan oleh Otoritas Jasa Keuangan (OJK). 


\section{PEMBAHASAN}

Aṭ-Ṭāhir bin 'Āsyūr memiliki gagasan bahwa dalam bidang transaksi pertukaran harta seperti 'aqad jual beli murabahah harus memenuhi 5 (lima) maqāsid, yaitu: sirkulasi (ar-rawāj), transparansi, kekuatan hukum, perlindungan (preservasi), dan keadilan. Suatu 'aqad transaksi pertukaran harta dipandang sah apabila kelima maqāṣid syarī'ah tersebut terpenuhi, jika salah satu maqāṣid tidak terpenuhi maka 'aqad tersebut pada dasarnya tidak sah ('Āsyūr, 2001). Analisis pemenuhan 5 (lima) maqāṣid oleh BPRS Mitra Mentari Sejahtera Ponorogo adalah sebagai berikut:

\section{Sirkulasi (ar-Rawāj)}

Menurut Aṭ-Ṭāhir bin 'Āsyūr, sirkulasi (ar-rawāj) merupakan bagian dari tujuan syariah (maqāșid syañ̄ah) agar 'aqad transaksi pertukaran harta dapat menciptakan distribusi atau perpindahan harta diantara manusia dengan caracara yang hak ('Āsyūr, 2001). Praktek sirkulasi (ar-rawāj]) di BPRS Mitra Mentari Sejahtera Ponorogo terlihat pada 2 (dua) aspek, yaitu:

\section{a. Perpindahan kepemilikan dari penjual kepada pembeli}

Pemindahan kepemilikan barang kepada pembeli di BPR Syariah Mitra Mentari Sejahtera terjadi apabila barang sudah dibeli nasabah berarti hak milik melekat pada nasabah meskipun nasabah membayarnya secara tangguh sebagai hutang/kewajiban atas pembelian barang kepada bank. Praktek tersebut telah mematuhi standar produk murabahah yang ditetapkan Otoritas Jasa Keuangan bahwa "Kepemilikan oleh nasabah diakui setelah bank menyerahkan obyek pembiayaan kepada nasabah setelah para pihak menyepakati kontrak murabahah (Standar No: 3.3.13)”.

\section{b. Pembayaran harga oleh pembeli kepada penjual}

Untuk mekanisme pembayaran, nasabah yang telah mendapatkan fasilitas pembiayaan murabahah dari BPR Syariah Mitra Mentari Sejahtera akan membayar angsuran setiap bulan dengan nominal tergantung pada besarnya pembiayaan dibagi dengan jangka waktu kemampuan nasabah membayar. Komponen pembayarannya adalah harga kulakan bank dan margin yang diharapkan oleh bank. Kemudian oleh BPR Syariah Mitra Mentari Sejahtera dicatat dalam akuntansi bisa menggunakan cara, yaitu 
anuitas atau flat dimana kedua cara tersebut dibenarkan oleh akuntansi syariah dan akuntansi Bank Indonesia serta dibolehkan oleh Otoritas Jasa Keuangan (Setiawan, 2018). Praktek tersebut telah mematuhi standar produk murabahah yang ditetapkan Otoritas Jasa Keuangan bahwa "Nasabah wajib melakukan pembayaran angsuran pembiayaan atas semua dana yang telah disalurkan Bank disertai dengan margin keuntungan yang menjadi hak Bank sesuai dengan jadwal pembayaran angsuran pembiayaan, yang merupakan satu kesatuan dengan 'aqad perjanjian (Standar: 3.12 .1 dan Standar 3.12.2)".

Berdasarkan praktek sirkulasi (ar-rawāj) di atas dapat terlihat bahwa BPR Syariah Mitra Mentari Sejahtera telah memenuhi maqāsid sirkulasi sangat baik sebagaimana yang digariskan oleh Aț-Ṭāhir bin 'Āsyūr yaitu dapat menciptakan distribusi barang obyek pembiayaan murabahah kepada nasabah dan juga mewujudkan perpindahan harta dari nasabah ke bank berupa margin dengan cara-cara yang hak. Kondisi ini menurut Sutinen dan Kuperan dapat disebabkan oleh motivasi ekstrinsik yaitu pengaruh sosial yang memiliki peranan penting dalam keputusan kelompok atau komunitas untuk memberikan penghargaan atau hukuman kepada anggota kelompoknya dalam bentuk menghubungkan atau memutus akses ke sumberdaya(Sutinen \& Kuperan, 1999). Dalam konteks perbankan, jika BPR Syariah Mitra Mentari Sejahtera menyimpang dari ketentuan standar produk murabahah yang ditetapkan Otoritas Jasa Keuangan berdampak pada hilangnya kepercayaan masyarakat kepada BPR Syariah Mitra Mentari Sejahtera sebagai lembaga intermediasi sekaligus simbol keagamaan sehingga bank syariah akan kesulitan mengakses dana pihak ketiga sebagai sumber dana penyaluran pembiayaan murabahah sebagaimana yang diungkap dari hasil penelitian Lee \& Ullah tentang perilaku nasabah bank Islam di Pakistan hampir 90\% responden menjawab akan menarik simpanan mereka jika bank Islam tidak patuh terhadap ketentuan syariah(Lee \& Ullah, 2011).

\section{Transparansi}

Menurut Aṭ-Ṭāhir bin 'Āsyūr, transparansi merupakan bagian dari tujuan syariah (maqūșid syan̄'ah) agar 'aqad transaksi pertukaran harta terhindar dari bahaya perselisihan dan pertengkaran, maka harus ada kejelasan bentuk atau wujud dan batasan harta yang ditransaksikan ('Āsyūr, 2001). Praktek 
transparansi di BPRS Mitra Mentari Sejahtera Ponorogo terlihat pada 3 (tiga) aspek, yaitu:

\section{a. Objek 'aqad dapat diserahkan}

Secara fisik BPR Syariah Mitra Mentari Sejahtera tidak menguasai obyek pembiayaan murabahah karena barang tersebut belum dikirim oleh suplier, namun BPR Syariah Mitra Mentari Sejahtera menguasai secara konstruktif melalui kegiatan pembelian barang tersebut baik secara transfer atau pembayaran langsung yang menjadikan barang tersebut secara sah dimiliki oleh BPR Syariah Mitra Mentari Sejahtera (Setiawan, 2018). Praktek tersebut telah mematuhi standar produk murabahah yang ditetapkan Otoritas Jasa Keuangan bahwa"Kepemilikan Obyek Pembiayaan harus sudah dalam penguasaan penjual baik dalam penguasaan fisik (qabdh haqiqi) ataupun penguasaan konstruktif (qabdh hukmi) (Standar: 3.3.10)".

\section{b. Obyek 'aqad harus berbentuk tertentu dan jelas}

Obyek pembiayaan murabahah di BPR Syariah Mitra Mentari Sejahtera adalah semua barang (aset berwujud) yang menjadi kebutuhan nasabah untuk kepentingan konsumsi dan investasi. Kepentingan konsumsi seperti sepeda motor dan mobil keluarga. Sedangkan kepentingan investasi seperti truk, rumah, stok barang dagangan, dan renovasi (Setiawan, 2018). Praktek tersebut telah mematuhi standar produk murabahah yang ditetapkan Otoritas Jasa Keuangan bahwa "Obyek Pembiayaan Murabahah dapat berupa aset berwujud (tangible assets) seperti barang dagangan, bahan baku produksi, aset properti, peralatan berat dan aset sejenis lainnya (Standar: 3.3.6 dan Standar 3.3.7)".

\section{c. Obyek 'aqad dapat ditransaksikan menurut syarak}

Agar obyek pembiayaan murabahah memenuhi ketentuan syariah, BPR Syariah Mitra Mentari Sejahtera melakukan tindakan preventif dengan cara melakukan analisa pembiayaan yang mendalam di awal pengajuan permohonan pembiayaan oleh nasabah agar tidak terjadi penyimpangan yang dilakukan oleh nasabah terkait penggunaan obyek pembiayaan murabahah pada saat ini atau di masa depan dan memastikan kembali melalui pernyataan tertulis dalam dokumen akad pembiayaan murabahah (Setiawan, 2018). Praktek tersebut telah mematuhi standar produk murabahah yang ditetapkan Otoritas Jasa Keuangan bahwa "Obyek 
Pembiayaan Murabahah maupun kegiatan usaha yang diselenggarakan menggunakan obyek pembiayaan tersebut harus terhindar dari sifat-sifat yang melanggar prinsip Syariah seperti: Riba, Maysir, Gharar, Haram, Zalim, Riswah (Suap) (Standar: 3.3.3)"

Berdasarkan praktek transparansi di atas dapat terlihat bahwa BPR Syariah Mitra Mentari Sejahtera telah memenuhi maqāsid transparansi dengan sangat baik sebagaimana yang digariskan oleh Aṭ-Ṭāhir bin 'Āsyūr yaitu harus ada kejelasan bentuk atau wujud dan batasan harta yang ditransaksikan agar terhindar dari bahaya perselisihan dan pertengkaran karena syarat objek 'aqad (mahallul al-'aqd) yang menjadi sasaran yang hendak dicapai oleh para pihak baik bank maupun nasabah melalui penutupan 'aqad mengikuti standar produk murabahah yang dikeluarkan oleh Otoritas Jasa Keuangan. Kondisi ini menurut Sutinen dan Kuperan (1999) dapat disebabkan oleh motivasi intrinsik yaitu mengikuti arahan lembaga yang memiliki kekuasaan untuk mengatur, mengawasi, dan melindungi industri jasa keuangan dalam hal ini adalah Otoritas Jasa Keuangan. BPR Syariah Mitra Mentari Sejahtera sebagai entitas bisnis memiliki tujuan mencari keuntungan (profit oriented), namun berada pada industri perbankan yang penuh dengan aturan. Maka cara mencari keuntungan BPR Syariah Mitra Mentari Sejahtera diatur dan diawasi secara ketat oleh regulasi Bank Indonesia, Otoritas Jasa Keuangan, dan fatwa Dewan Syariah Nasional. Sehingga praktek transparansi harus mengikuti ketentuan standar produk murabahah Otoritas Jasa Keuangan.

\section{Kekuatan hukum}

Menurut Aț-Tāair bin 'Āsyūr, kekuatan hukum merupakan bagian dari tujuan syariah (maqāṣid syan̄'ah) agar 'aqad transaksi pertukaran harta memberikan kekuatan hukum terhadap pemindahan kepemilikan harta diantara pihak yang bertransaksi ('Āsyūr, 2001). Praktek kekuatan hukum di BPRS Mitra Mentari Sejahtera Ponorogo terlihat pada 2 (dua) aspek, yaitu:

\section{a. Para pihak yang memenuhi syarat}

Syarat pengajuan pembiayaan murabahah di BPR Syariah Mitra Mentari Sejahtera adalah nasabah harus cukup umur dari segi hukum positif untuk melakukan tindakan hukum yaitu mereka yang berusia 21 tahun ke atas atau sudah menikah (Setiawan, 2018). Praktek tersebut telah mematuhi 
standar produk murabahah yang ditetapkan Otoritas Jasa Keuangan bahwa "Para pihak dalam kontrak Murabahah harus mempunyai kapasitas hukum untuk melaksanakan kontrak (Standar: 3.4.2)"

\section{b. Pernyataan kehendak yang memenuhi syarat}

Pernyataan kehendak antara nasabah dan bank harus memenuhi syarat adanya kesatuan majelis dan keridhoan dari kedua belah pihak yang berakad. Praktek kesatuan majelis 'aqad dalam proses penawaran (ijab) dan penerimaan (qabul) di BPR Syariah Mitra Mentari Sejahtera yaitu sebelum nasabah menandatangani 'aqad pembiayaan BPR Syariah Mitra Mentari Sejahtera, bank terlebih dahulu mengajukan surat penawaran (offering letter) kepada nasabah sesuai dengan kebutuhan nasabah. Jika nasabah tanda tangan pada offering letter berarti nasabah setuju dengan penawaran bank. Kemudian bank melakukan pengadaan barang. Setelah barang dimiliki oleh bank secara prinsip, bank mengundang nasabah ke kantor untuk melakukan 'aqad murabahah dengan menyepakati ketentuan-ketentuan yang tertera dalam 'aqad pembiayaan murabahah melalui tanda tangan kedua belah pihak yaitu bank dan nasabah sebagai wujud adanya keridhoan dari kedua belah pihak (Setiawan, 2018). Praktek tersebut telah mematuhi standar produk murabahah yang ditetapkan Otoritas Jasa Keuangan bahwa "Kontrak Murabahah harus disertai dengan penawaran (ijab) dan penerimaan (qabul) dari kedua belah pihak (Standar: 3.4.4)".

Berdasarkan praktek kekuatan hukum di atas dapat terlihat bahwa BPR Syariah Mitra Mentari Sejahtera telah memenuhi maqāṣid kekuatan hukum dengan sangat baik sebagaimana yang digariskan oleh Aț-Tāair bin 'Āsyūr yaitu dapat memberikan kekuatan hukum terhadap pemindahan kepemilikan harta diantara pihak yang bertransaksi. Kondisi ini menurut Sutinen dan Kuperan dapat disebabkan oleh motivasi intrinsik yaitu moral individu masing-masing pegawai BPR Syariah Mitra Mentari Sejahtera yaitu keharusan untuk berperilaku benar sesuai dengan ketentuan hukum yang didorong oleh faktor psikologi dan norma sosial(Sutinen \& Kuperan, 1999).

Secara psikologis, perilaku pegawai BPR Syariah Mitra Mentari Sejahtera didorong oleh moral untuk bertindak sesuai dengan aturan hukum. Misalnya sebagai syarat para pihak yang bertransaksi harus memiliki kapasitas hukum, maka para pegawai BPR Syariah Mitra Mentari Sejahtera berpedoman pada Kartu Tanda Penduduk (KTP) terhadap persetujuan nasabah yang mengajukan 
pembiayaan murabahah karena orang yang dapat membuat KTP dianggap dewasa yaitu berusia 18 tahun dan dapat melakukan tindakan hukum. Sehingga KTP menjadi syarat mutlak dalam pengajuan pembiayaan murabahah, jika belum memiliki KTP maka dapat diwakilkan oleh walinya atau orang tuanya. Secara normatif, pegawai BPR Syariah Mitra Mentari Sejahtera cenderung untuk mematuhi peraturan atau hukum yang sesuai dengan norma yang tertanam dalam diri individu. Misalnya, syarat para pihak yang bertransaksi harus cakap hukum adalah usia dewasa merupakan norma atau aturan yang ada dalam lingkungan sosial dan tertanam dalam diri pegawai BPR Syariah Mitra Mentari Sejahtera, karena orang yang belum dewasa seperti anak-anak dianggap tidak memiliki kapasitas hukum untuk membuat perjanjian atau perikatan.

\section{Preservasi}

Menurut Aț-Tāhir bin 'Āsyūr, preservasi merupakan bagian dari tujuan syariah (maqāșid syan̄'ah) agar 'aqad transaksi pertukaran harta dapat menciptakan perlindungan terhadap harta dari pemindahan kepemilikan secara batil ('Āsyūr, 2001). Praktek preservasi di BPRS Mitra Mentari Sejahtera Ponorogo terlihat pada 2 (dua) aspek, yaitu:

\section{a. Kewajiban memenuhi 'aqad}

Agar transaksi jual beli murabahah di BPR Syariah Mitra Mentari Sejahtera memiliki legalitas yang kuat, maka dibuatkan 'aqad pembiayaan murabahah yang tertulis dan ditandatangani oleh pihak bank dan nasabah sehingga mengikat pihak-pihak tersebut untuk bertanggungjawab melaksanakan ketentuan-ketentuan yang tertuang di dalam 'aqad pembiayaan murabahah (Setiawan, 2018). Praktek tersebut telah mematuhi standar produk murabahah yang ditetapkan Otoritas Jasa Keuangan bahwa "Para pihak harus terikat pada seluruh ketentuan dalam kontrak yang telah disepakati oleh kedua belah pihak yang mana seluruh ketentuan tersebut tidak ada satu pun yang melanggar kepatuhan prinsip syariah d idalamnya (Standar: 3.4.6)"

\section{b. Tanggungjawab terhadap ‘aqad}

BPR Syariah Mitra Mentari Sejahtera tidak mengenakan denda kepada nasabah yang telat melakukan pembayaran angsuran. Karena bagi BPR 
Syariah Mitra Mentari Sejahtera tidak dapat mengakui penerimaan dari denda sebagai keuntungan dalam pencatatan akuntansi bank, maka tidak ada mekanisme denda di BPR Syariah Mitra Mentari Sejahtera. Sedangkan untuk menimbulkan efek jera kepada nasabah yang telat membayar cukup dilakukan secara verbal dengan pendekatan sisi religuisitas nasabah (Setiawan, 2018). Praktek tersebut tidak mematuhi standar produk murabahah yang ditetapkan Otoritas Jasa Keuangan bahwa "Denda atas tunggakan (ta'zir) hanya dikenakan kepada Nasabah jika Nasabah terbukti lalai atas kewajiban pembayaran angsurannya (Standar: 3.20.4)".

Berdasarkan praktek preservasi di atas dapat terlihat bahwa BPR Syariah Mitra Mentari Sejahtera tidak memenuhi maqāsid preservasi sebagaimana yang digariskan oleh Aț-Ṭāhir bin 'Āsyūr yaitu menciptakan perlindungan terhadap harta dari pemindahan kepemilikan secara batil. Kondisi ini terjadi karena tidak terdapatnya ketentuan denda dalam pembiayaan murabahah di BPR Syariah Mitra Mentari Sejahtera mengisyaratkan bahwa BPR Syariah Mitra Mentari Sejahtera tidak mematuhi standar produk murabahah yang ditetapkan Otoritas Jasa Keuangan tentang ketentuan denda, hal ini menurut Stover dan Brown (1975) dapat disebabkan oleh faktor nilai lebih yang diharapkan(Stover \& Brown, 1975), yaitu berupa kebanggaan sosial yang berorentasi simpati nasabah bahwa BPR Syariah Mitra Mentari Sejahtera lebih manusiawi dibandingkan bank syariah/konvensional lainnya karena untuk membayar cicilan harga pokoknya saja nasabah sudah tidak mampu membayar apalagi disuruh untuk membayar denda dari keterlambatan membayar cicilan tersebut. Kebanggaan sosial sebagai nilai yang diharapkan dari tidak mematuhi ketentuan denda sangat relevan dengan kondisi BPR Syariah Mitra Mentari Sejahtera sebagai pendatang baru dan masih dalam tahap pengenalan pasar di wilayah Ponorogo.

Namun, pentingnya ketentuan denda dalam akad murabahah berdasarkan prinsip ta'zir, yaitu bertujuan agar nasabah lebih disiplin dalam melaksanakan kewajibannya. Menurut Fatwa Dewan Syariah Nasional Nomer: 17/DSN-MUI/IX/2000 tentang sanksi atas nasabah yang mampu menundanunda pembayaran bahwa sanksi dalam bentuk denda sejumlah uang diperuntukkan terutama bagi nasabah dengan kategori: 1) nasabah yang mampu membayar, tetapi menunda-nunda pembayaran dengan disengaja, dan 2) nasabah yang tidak mempunyai kemauan dan itikad baik untuk membayar hutangnya. Jika tidak ada ketentuan denda, perilaku nasabah tidak disiplin 
dalam melaksanakan kewajiban untuk mengangsur harga pokok dan margin dari pembiayaan murabahah setiap bulannya

Tidak adanya ketentuan denda dan ganti rugi dalam pembiayaan murabahah di BPR Syariah Mitra Mentari Sejahtera menurut Aț-Ṭāhir bin 'Āsyūr akan berdampak pada lemahnya perlindungan terhadap harta dari pemindahan kepemilikan secara batil. Akibat kurang tanggungjawab terhadap 'aqad oleh pihak nasabah. Untuk mewujudkan perlindungan harta, BPR Syariah Mitra Mentari Sejahtera harus mematuhi secara penuh standar produk murabahah yang dikeluarkan oleh Otoritas Jasa Keuangan dan fatwa Dewan Syariah Nasional agar terhindar dari risiko kredit yang berdampak pada tingginya angka Non Performing Financing (NPF) sehingga membahayakan tingkat kesehatan BPR Syariah Mitra Mentari Sejahtera.

\section{Keadilan}

Menurut Aț-Tāahir bin 'Āsyūr, keadilan merupakan bagian dari tujuan syariah (maqāșid syan̄‘ah) agar 'aqad transaksi pertukaran harta tidak merugikan pihak lain dalam hal pemerolehan harta ('Āsyūr, 2001). Praktek preservasi di BPRS Mitra Mentari Sejahtera Ponorogo terlihat pada 3 (tiga) aspek, yaitu:

\section{a. Keseimbangan dalam transaksi}

Transaksi pembiayaan murabahah di BPR Syariah Mitra Mentari Sejahtera dalam rangka memenuhi kebutuhan para pihak yang bertransaksi. Pada sisi bank, BPR Syariah Mitra Mentari Sejahtera mendapatkan keuntungan atau margin yang diharapkan besarnya sesuai dengan jangka waktu kemampuan nasabah dalam mengembalikan pembiayaan. Sedangkan pada sisi nasabah mendapatkan kemudahan dan bantuan dalam pengadaan barang yang menjadi kebutuhan nasabah untuk memperlancar kepentingan bisnis nasabah (Setiawan, 2018). Praktek tersebut telah mematuhi standar produk murabahah yang ditetapkan Otoritas Jasa Keuangan bahwa "Saling menguntungkan (setiap 'aqad dilakukan untuk memenuhi kepentingan para pihak sehingga terhindar dari manipulasi) (Standar: 10.2.24.e)". 


\section{b. Keseimbangan memikul risiko}

Adanya kesataraan hak dan kewajiban antara nasabah dengan BPR Syariah Mitra Mentari Sejahtera terlihat pada bank memiliki kewajiban memberikan fasilitas pembiayaan kepada nasabah untuk pembelian barang sesuai dengan kebutuhannya. Dengan kata lain, nasabah berhak mendapatkan fasilitas pembiayaan murabahah dari bank untuk pembelian barang sesuai dengan kebutuhan nasabah. Sedangkan kewajiban nasabah untuk membayar seluruh jumlah kewajiban pada saat jatuh tempo. Dengan kata lain, bank berhak mendapatkan pengembalian seluruh kewajiban dari nasabah yang terdiri dari harga beli ditambah dengan margin/keuntungan yang diharapkan bank (Setiawan, 2018). Praktek tersebut telah mematuhi standar produk murabahah yang ditetapkan Otoritas Jasa Keuangan bahwa"Kesetaraan atau taswiyah (para pihak yang melaksanakan 'aqad memiliki kedudukan yang setara, memiliki hak dan kewajiban yang seimbang) (Standar: 10.2.24.)".

\section{c. Kesempatan melakukan negoisasi klausul ‘aqad}

Kesempatan bermusyawarah tercermin pada BPR Syariah Mitra Mentari Sejahtera memberikan penawaran ulang kepada nasabah yang merasa keberatan dengan klausal yang tertulis pada 'aqad pembiayaan murabahah seperti masalah margin bank. BPR Syariah Mitra Mentari Sejahtera memberi penawaran ulang kembali, kepada nasabah dengan pertimbangan aspek bisnis dan aspek emosional. Contoh aspek bisnis adalah: laba rugi bank, nasabah inti, rekam jejak nasabah, pengaruh nasabah pada suatu komunitas. Sedangkan contoh aspek emosional adalah: profil ghiroh keislaman nasabah yang kuat, komitmen ke syariah kuat, terus usahanya lancar, dan semangat dakwahnya luar bisa (Setiawan, 2018). Praktek tersebut telah mematuhi standar produk murabahah yang ditetapkan Otoritas Jasa Keuangan bahwa"Pihak Bank harus selalu memberikan kesempatan bermusyawarah dengan calon Nasabah terkait klausul standar perjanjian atau 'aqad Murabahah yang memberatkan (Standar: 10.2.2)".

Berdasarkan praktek kekuatan hukum di atas dapat terlihat bahwa BPR Syariah Mitra Mentari Sejahtera telah memenuhi maqāsid keadilan dengan sangat baik sebagaimana yang digariskan oleh Aṭ-Ṭāhir bin 'Āsyūr yaitu tidak merugikan pihak lain dalam hal mendapatkan harta. Kondisi ini menurut Sutinen dan Kuperan dapat disebabkan oleh motivasi ekstrinsik yaitu pengaruh 
sosial yang memiliki peranan penting dalam keputusan kelompok atau komunitas untuk memberikan penghargaan atau hukuman kepada anggota kelompoknya dalam bentuk menghubungkan atau memutus akses ke sumberdaya(Sutinen \& Kuperan, 1999). Dalam konteks perbankan, jika BPR Syariah Mitra Mentari Sejahtera menyimpang dari ketentuan standar produk murabahah yang ditetapkan Otoritas Jasa Keuangan berdampak pada hilangnya kepercayaan masyarakat kepada BPR Syariah Mitra Mentari Sejahtera sebagai lembaga intermediasi sekaligus simbol keagamaan sehingga bank syariah akan kesulitan mengakses dana pihak ketiga sebagai sumber dana penyaluran pembiayaan murabahah dan pada gilirannya dapat mengurangi profit BPR Syariah Mitra Mentari Sejahtera. Temuan ini sekaligus memberikan bukti atas pendapat Mohammad \& Shahwan bahwa banyak bank syariah yang hanya berorentasi pada keuntungan bukan berdasarkan tujuan sosial jika dilihat dari perspektif maqasid syariah (Mohammed \& Shahwan, 2013).

\section{SIMPULAN}

Berdasarkan analisis pemenuhan 5 (lima) maqāṣid oleh BPR Syariah Mitra Mentari Sejahtera Ponorogo dapat disimpulkan bahwa BPR Syariah Mitra Mentari Sejahtera Ponorogo telah memenuhi maqāṣid sirkulasi, maqāṣid transparansi, maqāṣid kekuatan hukum, dan maqāsid keadilan dengan sangat baik, kecuali maqāsid preservasi sehingga transaksi pembiayaan murabahah di BPR Syariah Mitra Mentari Sejahtera Ponorogo dinyatakan sah karena telah memenuhi 5 (lima) maqāṣid tersebut sebagaimana yang digariskan oleh Aṭ-Ṭāhir bin 'Āsyūr bahwa transaksi pertukaran harta harus: 1) menciptakan distribusi barang obyek pembiayaan murabahah kepada nasabah dan juga mewujudkan perpindahan harta dari nasabah ke bank berupa margin dengan cara-cara yang hak, 2) adanya kejelasan bentuk atau wujud dan batasan harta yang ditransaksikan agar terhindar dari bahaya perselisihan dan pertengkaran, 3) memberikan kekuatan hukum terhadap pemindahan kepemilikan harta diantara pihak yang bertransaksi, 4) menciptakan perlindungan terhadap harta dari pemindahan kepemilikan secara batil, dan 5) tidak merugikan pihak lain dalam hal mendapatkan harta. Implikasi dari penelitian ini adalah hendaknya praktisi perbankan syariah menggunakan maqāṣid syarī'ah konsepsi aṭ-Tāhir bin 'Āsyūr sebagai assesment kepatuhan bank syariah terhadap ketentuan pembiayaan murabahah. 


\section{DAFTAR PUSTAKA}

'Āsyūr, M. aț-Tāàhir bin. (2001). Maqāṣid asy-Syarī’ah al-Islāmiyah. Dār an-Nafā is.

Aditiasari, D. (2017). 7 Hambatan yang Buat Bank Syariah Lambat Berkembang di RI. https://finance.detik.com/moneter/3076959/7-hambatan-yang-buatbank-syariah-lambat-berkembang-di-ri

Afrianto, D. (2018). Market Share Perbankan Syariah Indonesia hanya 5,3\%, Jokowi: Di Malaysia sudah 23,8\%. https://economy.okezone.com/read/2017/07/27/320/1745134/marketshare-perbankan-syariah-indonesia-hanya-5-3-jokowi-di-malaysia-sudah23-8

Al-Galy, B. (1996). Syaikh Al-Jami' Al-A'zam Muhammad At-tāhir bin 'Asyūr: Hayatuhu wa Asaruhu. Dār Ibn Ḥazm.

Anwar, S. (2007). Hukum Perjanjian Syariah: Studi tentang Teori 'aqad dalam Fikih Muamalat. PT RajaGrafindo Persada.

Dusuki, A. W., \& Abozaid, A. (2007). A Critical Appraisal On The Challenges of Realizing Maqasid Al-Shariaah In Islamic Banking And Finance. IIUM Journal of Economics and Management, 15(2), 999-1000.

Ibrahim, Z. (2015). Menggugat Bank Syariah. http://www.metrosulawesi.com/article/menggugat-bank-syariah-0, tanggal 9 Mei, 2015

Lee, K. ho, \& Ullah, S. (2011). Customers' Attitude Toward Islamic Banking in Pakistan. International Journal of Islamic and Middle Eastern Finance and Management, 4(2), 131-145.

Mohammed, M. O., Razak, D. A., \& Taib, M. F. (2008). The Performance Measures of Islamic Bankinng Based on The Maqasid Framework. The IIUM International Accounting Conference (INTAC IV), 1-29.

Mohammed, M. O., \& Shahwan, S. (2013). The Objective of Islamic Economic and Islamic Banking in Light of Maqasid Al-Shariah: A Critical Review. MiddleEast Journal of Scientific Research 13 (Research in ContemporaryIslamic Finance and Wealth Management), 13, 75-84. 
Moleong, L. J. (2005). Metodologi Penelitian Kualitatif. PT. Remaja Rosdakarya.

Otoritas Jasa Keuangan. (2016). Standar Produk Perbankan Syariah Murabahah. Otoritas Jasa Keuangan.

Otoritas Jasa Keuangan. (2018). Siaran Pers: Market Share Keuangan Syariah Capai 8 Persen. https://www.ojk.go.id/id/berita-dan-kegiatan/siaranpers/Pages/Siaran-Pers-Market-Share-Keuangan-Syariah-Capai-8-

Persen.aspx

Rosly, S. A. (2010). Shariah Paramaters Reconsidered. International Journal of Islamic and Middle Eastern and Management, 3(2), 132-146.

Stover, R. V., \& Brown, D. W. (1975). Understanding Compliance and Noncompliance With Law: The Contributions of Utility Theory. Social Science Quarterly, 56(3), 363-375.

Sugiyono. (2008). Metode Penelitian Bisnis (Pendekatan Kuantitatif, Kualitatif dan $R \& D)$. Alfabeta.

Sulaiman, S. (2016). Penyimpangan Akad Murābahah Pada Perbankan Syariah di Indonesia. Iqtishodia: Jurnal Ekonomi Syariah, 1(2), 1-16.

Sutinen, J. G., \& Kuperan, K. (1999). A Socio-Economic Theory of Regulatory Compliance. International Journal of Social Economics, 26(1/2/3), 174-193.

Yusuf, A. M. (2014). Metode Penelitian Kuantitatif, Kualitatif dan Penelitian Gabungan (Pertama). Kencana. 
